\title{
Identification of Bulge Stem Cells in Mouse and Human Hair Follicles
}

\author{
Bélgica J. Molina ${ }^{1,2 *}$, Elda Giansante² ${ }^{2}$ Héctor J. Finol ${ }^{1}$ \\ ${ }^{1}$ Center of Electron Microscopy, Science Faculty, Central University of Venezuela, Caracas, Venezuela \\ ${ }^{2}$ Dermatology Service University Hospital of Caracas, Caracas, Venezuela \\ Email: ^belgikcel@gmail.com
}

How to cite this paper: Molina, B.J. Giansante, E. and Finol, H.J. (2018) Identification of Bulge Stem Cells in Mouse and Human Hair Follicles. Microscopy $R e$ search, 6, 19-29.

https://doi.org/10.4236/mr.2018.63003

Received: June 18, 2018

Accepted: July 19, 2018

Published: July 22, 2018

Copyright (c) 2018 by authors and Scientific Research Publishing Inc. This work is licensed under the Creative Commons Attribution International License (CC BY 4.0).

http://creativecommons.org/licenses/by/4.0/

(c) (i) Open Access

\begin{abstract}
The skin contains various populaions of stem cells, but its characterization has been hampered by lack of markers and unclear location. The hair follicle has a niche for stem cells called a "bulge" which acts as a reservoir of multipotent stem cells. In the study reported here, an immunohistochemical and immunofluorescence analysis was performed on mouse and human tissues in order to determine the possible presence of stem cells of hair follicle through cytokeratin 15 (CK15), CD34, and CD200 markers identified as crucial to the stem cells and to identify the bulge region. Mouse $(n=7)$ and human $(\mathrm{n}=7)$ skin samples were used. The expression of proteins was determined by the indirect immunoperoxidase technique and a secondary antibody bound to a fluorochrome. The specificity of staining was evaluated by negative controls. The results revealed that the stem cells associated with CD34 and CD200 antibodies were differentially expressed in the interfollicular epidermis, sebaceous glands, and bulge region, indicating that, in mice, CD34 and, in humans, CD200 are more specific than CK15 in detecting bulge cells. It also suggests that CD34 is specific for mouse bulge cells, while CD200 might have specificity for progenitor cells and partially differentiated cells in humans.
\end{abstract}

\section{Keywords}

Stem Cells, Hair Follicle, Bulge, CD34, CD200

\section{Introduction}

The epithelium of mammalian skin is known to contain permanently residing stem cells (SC) that are able to maintain multiple differentiated lineages in the interfollicular epidermis (IFE), hair follicle (HF), and sebaceous gland (SG) [1]. 
In this regard, the $\mathrm{HF}$ is one of the most complex miniorgans in the bodies of mammals [2] [3]. The adult HF consists of an upper portion that is permanent and a lower portion that constantly remodels during the hair's cycle of: growth (anagen), degeneration (catagen), and rest (telogen), and the cyclical nature of hair growth is thought to be dependent on HF stem cells [4] [5]. They are located in specific regions of tissue called "niches" and remain in a state of quiescence, to be activated by disease or alterations of physiological processes caused by tissue injury. Stem cell niches are discrete, dynamic, and functional microenvironments, domains that influence SCs' ability to govern tissue homeostasis and repair throughout the lifetime of an organism [6]. The niches' main function is to maintain and repair the tissue or organ in which they are located [7]. The mammalian HF has a niche for SC called the "bulge" region is a segment of the outer root sheath (ORS) adjacent to the site of attachment of the arrector pili muscle [8]. Stem cells located in the HF bulge area give rise to the follicle structures during each anagen phase [9].

Several putative biomarkers have been suggested for identifying SC in murine and human HF; however, these results show discrepancies. The purpose of our study was the identification of bulge region in mouse and human HF, and to determine the patterns of biomarker expression of proteins CK15, CD34 and CD200 by immunohistochemistry and immunofluorescence in order to find the reliable molecular markers. The potential biomarkers could be useful in characterizing and isolating follicular SC in mice and humans.

\section{Materials and Methods}

\subsection{Tissue Samples}

Mice, 2 - 3 days old $(n=7)$, were sacrificed, and follicles were obtained from the skin of the body and from the vibrissae. Healthy human scalp skin was obtained from facelift patients $(n=7)$ with the approval of the ethical committee of the Faculty of Sciences of the Central University of Venezuela.

\subsection{Histopathology}

In order to observe the morphology of bulge in vivo in mouse and human, the skins with HF were fixed overnight in $4 \%$ neutral-buffered paraformaldehyde and transferred to $70 \%$ ethanol. They were then embedded in paraffin, sectioned at $8 \mu \mathrm{m}$, and stained with blue toluidine and hematoxylin eosin (H\&E).

For the immunohistochemistry and immunofluorescence studies, the skin with HF was immediately frozen in Thermo OCT compound (Sakura Finetek, Tokyo, Japan). Consecutive 8- $\mu \mathrm{m}$-thick sections were sliced with a cryostat and mounted serially on separate slides for three different immunostains against (cytokeratin 15, clone LHK15; Thermo, Lab Vision, Fremont, CA), cluster of differentiation CD34 (also known as mucosialin) (BD Biosciences, San Jose, $\mathrm{CA}$ ), and CD200 (known as OX2) (BD Biosciences). 


\subsection{Immunohistochemistry}

Frozen sections were defrosted, air dried for 3 hours, and fixed with acetone for $10 \mathrm{~min}$. at $20^{\circ} \mathrm{C}$. They were then incubated with primary antibodies (diluted 1:100) overnight at $4^{\circ} \mathrm{C}$. The next day, the sections were rinsed for 3 - 5 minutes to remove unbound primary antibodies. Subsequently they were incubated for $30 \mathrm{~min}$. at room temperature with biotinylated secondary antibodies (anti-rabbit and anti-mouse immunoglobulins), which form a complex with peroxidaseconjugated streptavidin molecules. Signal was detected using the Dako Cytomation (Carpinteria, CA), with diaminobenzidine as the chromagen, following the manufacturer's protocol. Tissues were counterstained in Harris hematoxylin (Sigma-Aldrich, St. Louis, MO). The specificity of staining was evaluated by negative controls in the absence of primary antibody. Labeled cells were observed, using an inverted microscopy-enable phase contrast and epifluorescence microscope (Axiovet 40, Carl-Zeiss, Göttingen, Germany).

\subsection{Immunofluorescence}

Frozen sections in OCT compound (Thermo Fisher Scientific, Germany) were sliced with a cryostat and mounted on slides. Sections were blocked with $10 \%$ horse serum, diluted 1:30, at room temperature for $25 \mathrm{~min}$ and then incubated with the first primary antibody (anti-mouse CK15, anti-mouse CD34 IgG [in mice], and anti-human CD200 IgG [in humans], diluted 1:100) at room temperature for $90 \mathrm{~min}$. After three consecutive washes, they were incubated with the second antibody (goat anti-mouse IgG conjugated with FITC for CK15 [in mouse and human], anti-rat IgG biotin [in mouse], and anti-mouse IgG biotin [in human]), diluted 1:100 at room temperature for $30 \mathrm{~min}$. Slides were washed three times and then incubated with Streptavidin PE for $30 \mathrm{~min}$ for CD34 and CD200. Slides were washed, counterstained, and treated with mounting medium containing 4,6-diamino-2-phenylindole (DAPI, Vector Laboratories, Burlingame, CA). Labeled cells were identified using an Olympus FluoView FV1000 confocal microscope (Tokyo, Japan) equipped with a video camera.

\section{Results}

\subsection{Morphology of the Bulge Region in Mouse and Human Skin}

Immunohistochemistry and immunofluorescence studies of mouse and human skin samples allowed us to appreciate the organization and distribution of the HF cells and to identify SC of the follicles as well as to estimate the sensitivity of the monoclonal antibodies (CK15 in mouse and human, monoclonal antibody a highly glycosylated, CD34 in mouse, and CD200 in human) which are considered specific markers of SC.

In histological sections of mouse and human skin, the structure and organization of HF were evident, and we were able to distinguish the location of the bulge region (Figure 1). The expression profiles of biomarkers are summarized (Table 1), with differences in longitudinal distribution of expression 
among CK15, CD34 and CD200.

\subsection{Differential Expression of Cytokeratin 15 in Mouse and Human Skin}

CK15 is an intermediate filament protein expressed in basal keratinocytes of stratified squamous epithelium [10] [11]. It is used as a marker of undifferentiated multipotent cells and is considered a biomarker for mouse and human

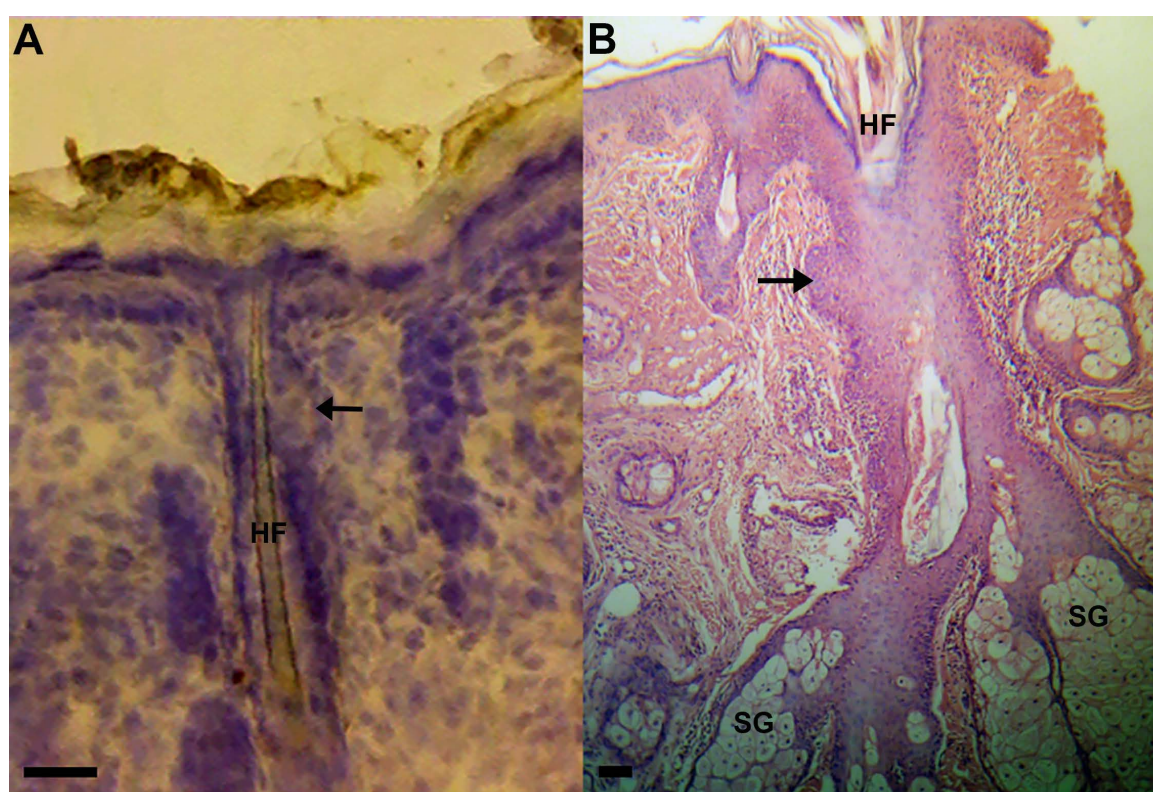

Figure 1. Anatomy of mouse and human anagen hair follicles, showing the bulge region. (A). Mouse, bulge region (arrow), hair (HF) (blue toluidine) Scale bars $=100 \mu \mathrm{m}$. (B). Human, bulge region (arrow), hair (HF), the SG duct (H \& E). Scale bars $=100 \mu \mathrm{m}$.

Table 1. Summary of immunohistochemical and immunofluorescence staining patterns in the epithelial components of mouse and human scalps and the anagen hair follicles.

\begin{tabular}{|c|c|c|c|c|c|c|c|c|c|c|c|c|}
\hline & \multicolumn{2}{|c|}{ Epidermis } & \multicolumn{10}{|c|}{ Hair Follicles } \\
\hline & \multicolumn{12}{|c|}{ Outer root sheath } \\
\hline & \multirow{2}{*}{\multicolumn{2}{|c|}{ SB }} & \multicolumn{2}{|c|}{ Infundibulum } & \multicolumn{2}{|c|}{$\begin{array}{l}\text { Bulge } \\
\text { region }\end{array}$} & \multirow{2}{*}{$\begin{array}{c}\text { SG } \\
\text { B }\end{array}$} & \multicolumn{2}{|c|}{$\begin{array}{c}\text { Sub } \\
\text { bulge }\end{array}$} & \multicolumn{2}{|c|}{$\begin{array}{c}\text { Lower } \\
\text { ORS }\end{array}$} & \multirow[t]{2}{*}{ Bulb } \\
\hline & & & B & SB & $\mathrm{B}$ & SB & & B & SB & B & $\mathrm{SB}$ & \\
\hline \multicolumn{13}{|c|}{ Mouse } \\
\hline CK15 & + & $+/-$ & + & + & + & + & ++ & + & + & $+/-$ & $+/-$ & - \\
\hline $\mathrm{CD} 34$ & $+/-$ & - & $+1-$ & $+1-$ & + & ++ & ++ & + & ++ & $+/-$ & $+/-$ & - \\
\hline \multicolumn{13}{|c|}{ Human } \\
\hline CK15 & ++ & - & $+1-$ & - & ++ & $+1-$ & + & - & - & $+/-$ & - & - \\
\hline CD200 & $+/-$ & - & + & + & ++ & ++ & ++ & ++ & ++ & $+1-$ & $+/-$ & - \\
\hline
\end{tabular}

The results obtained in this study, using the CK15, CD34, and CD200 antibodies, showed that staining intensities were: $(-)$ : no staining; $(+/-)$ : partially slightly positive staining; $(+)$ : positive staining; and $(++)$ : strongly positive staining. B: basal cell, SB: suprabasal cells, ORS: outer root sheath, SG: sebaceous gland. 
follicular SC that reside in the bulge [12] [13] [14] [15]. The results of the immunohistochemistry and immunofluorescence analyses (Table 1) for mice and humans showed strong CK15 staining in the basal IFE, moderate staining in the outermost layer of the bulge ORS, the proximal isthmus, infundibulum, and outermost layer of the sub-bulge ORS, suggesting the presence of undifferentiated cells. The controls were negative in the bulge region.

\subsection{Expression of CD34 in the ORS Proximal Isthmus, the Infundibulum and the Bulge Region in Mouse Skin}

Cluster of differentiation $34(\mathrm{CD} 34)$ is a surface glycoprotein $(105-120 \mathrm{kDa})$, expressed on early hematopoietic stem and progenitor cells [16], and functions as an important factor in cell-cell adhesion [17] [18]. Mouse immunohistochemistry and immunofluorescence demonstrated differential expression patterns of CD34 (Table 1), (Figure 2 and Figure 3). We found CD34 staining in some cells in the basal IFE (Figure 2 and Figure 3), and SG duct.

\subsection{Expression of CD200 in the Basal IFE and the Bulge Region in Human Skin}

The Ox-2 membrane glycoprotein, also called CD200, a member of the immunoglobulin superfamily, is involved in controlling the activation of macrophages and granulocytes [19].

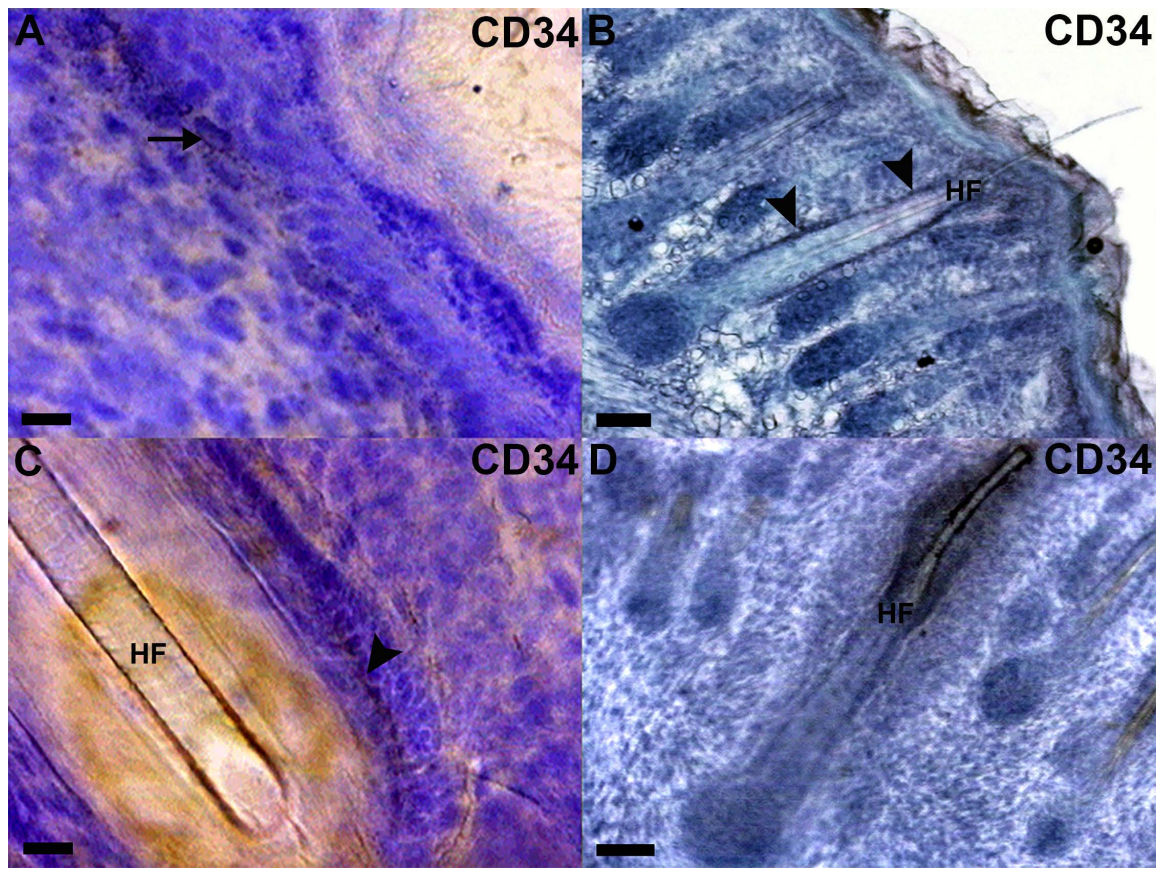

Figure 2. Immunohistochemical determination of CD34 in histological sections of mouse anagen hair follicles. Light microscope. (A). CD200 stained section showing brown-colored cells in the basal layer of the IFE (arrow) Scale bar $=20 \mu \mathrm{m}$. (B), (C). CD34 positive in the ORS proximal isthmus (arrowhead) and the infundibulum and the bulge region (arrowhead) ((B) Scale bar $=100 \mu \mathrm{m}$. (C) Scale bar $=20 \mu \mathrm{m}$.). (D). Negative control Scale bar $=$ $100 \mu \mathrm{m}$. 

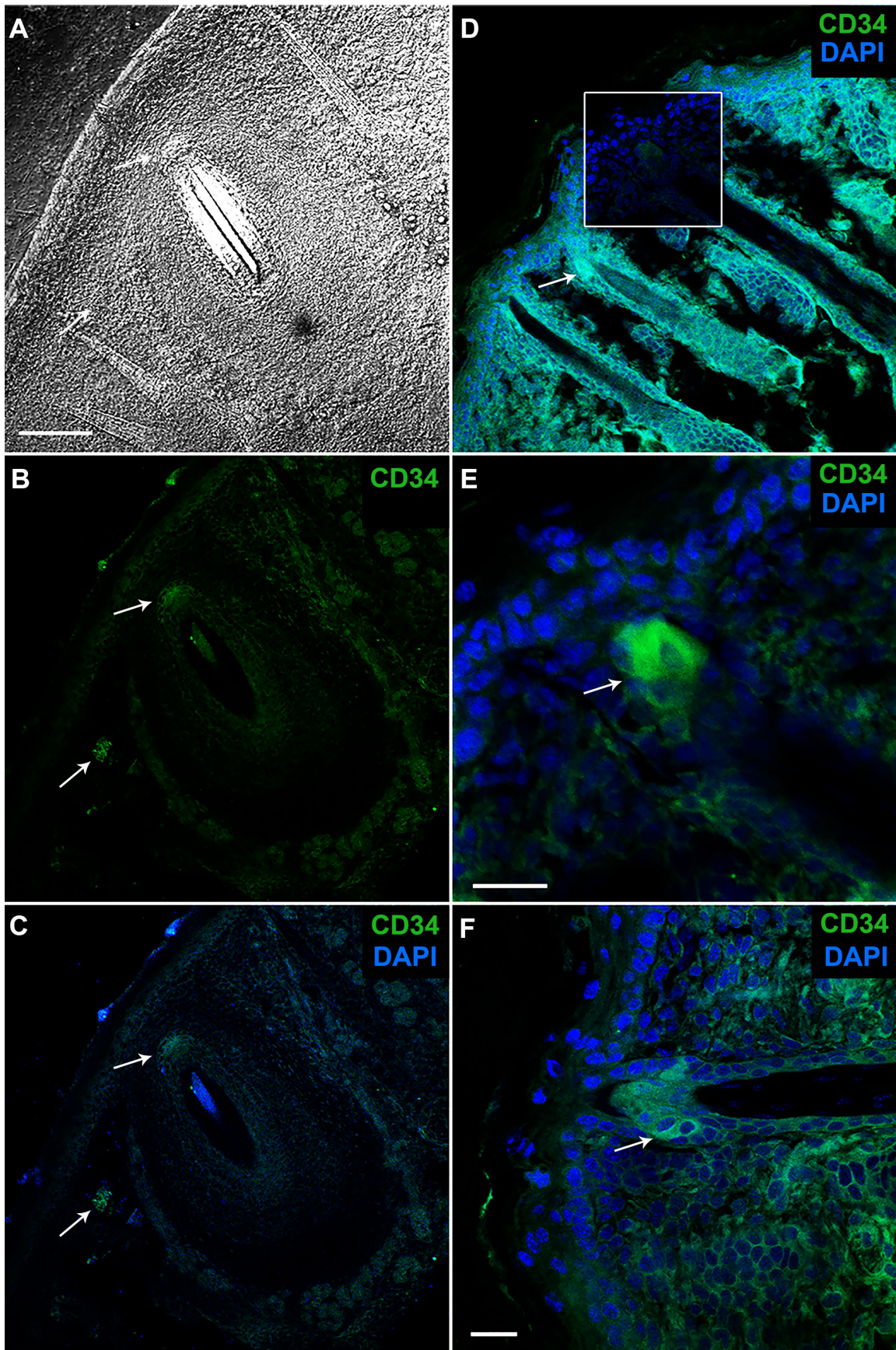

Figure 3. Immunofluorescence of longitudinally sectioned mouse vibrissae (A)-(C) and HF (D)-(E) stained for CD34. Confocal microscope. (A) Panoramic view showing the organization of the whiskers in the skin. Image DIC. (B), (C). High CD34 expression in all areas of the bulge region (arrows) and moderate expression in cells of the SG surrounding the whiskers. (C)-(F). High CD34 expression in the bulge region (arrow) and moderate expression in cells of the basal SG. Sum of images (blue and green). Nuclei are counterstained with DAPI. Scale bars $=100 \mu \mathrm{m}$.

In the present investigation, immunohistochemistry and immunofluorescence showed slight to moderate CD200 staining in the basal IFE and strong staining in the outermost layer of the bulge ORS, the infundibulum, and the 
SG duct (Table 1, Figure 4 and Figure 5). In addition, the controls' reaction was negative in the bulge region (Figure $5(\mathrm{~A})$ ).

\section{Discussion}

Our immunohistochemistry and immunofluorescence assessment of follicle sections revealed that SC-associated biomarkers are differentially expressed in the epidermis and anagen hair follicles. Similar results in the immunofluorescence of cytokeratin 15 in mouse and human were also found as a homogeneous staining expressed in epidermal basal keratinocytes, in the outermost layer of the bulge ORS, the proximal isthmus, infundibulum, and outermost layer of the sub-bulge ORS, as reported previously [13] CK15 is not a specific of the bulge. However, the positive expression of CK15 is preferably located in the bulge region in the human scalp, and this expression is absent in the basal IFE [12] [20]. A pattern similar to previous reports indicates that CD34 is the best marker to delineate SC in the bulge region in murine models [21] [22] [23]. Also, it has been suggested that the CD34 antibody is an excellent mouse follicular cells and is not present in the cell marker of the human RPFP [24]; coinciding with our results indicating that $\mathrm{CD} 34$ give an important role in bulge cells. CD200 was highly expressed in all areas of the bulge region, consistent with previous reports identifying it as a possible SC niche [12] [15] [25] [26], in contrast to mouse bulge cells.

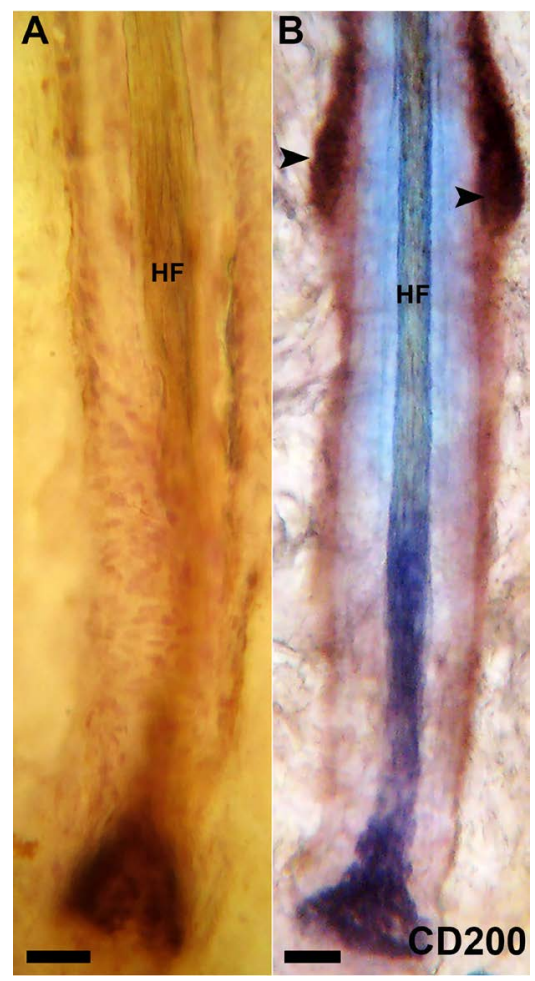

Figure 4. Immunohistochemical determination of CD200 in histological sections of anagen hair follicles of mouse. Light microscope. (A). Negative control. (B). CD200 staining in the bulge (arrowhead) Scale bars $=100 \mu \mathrm{m}$. 


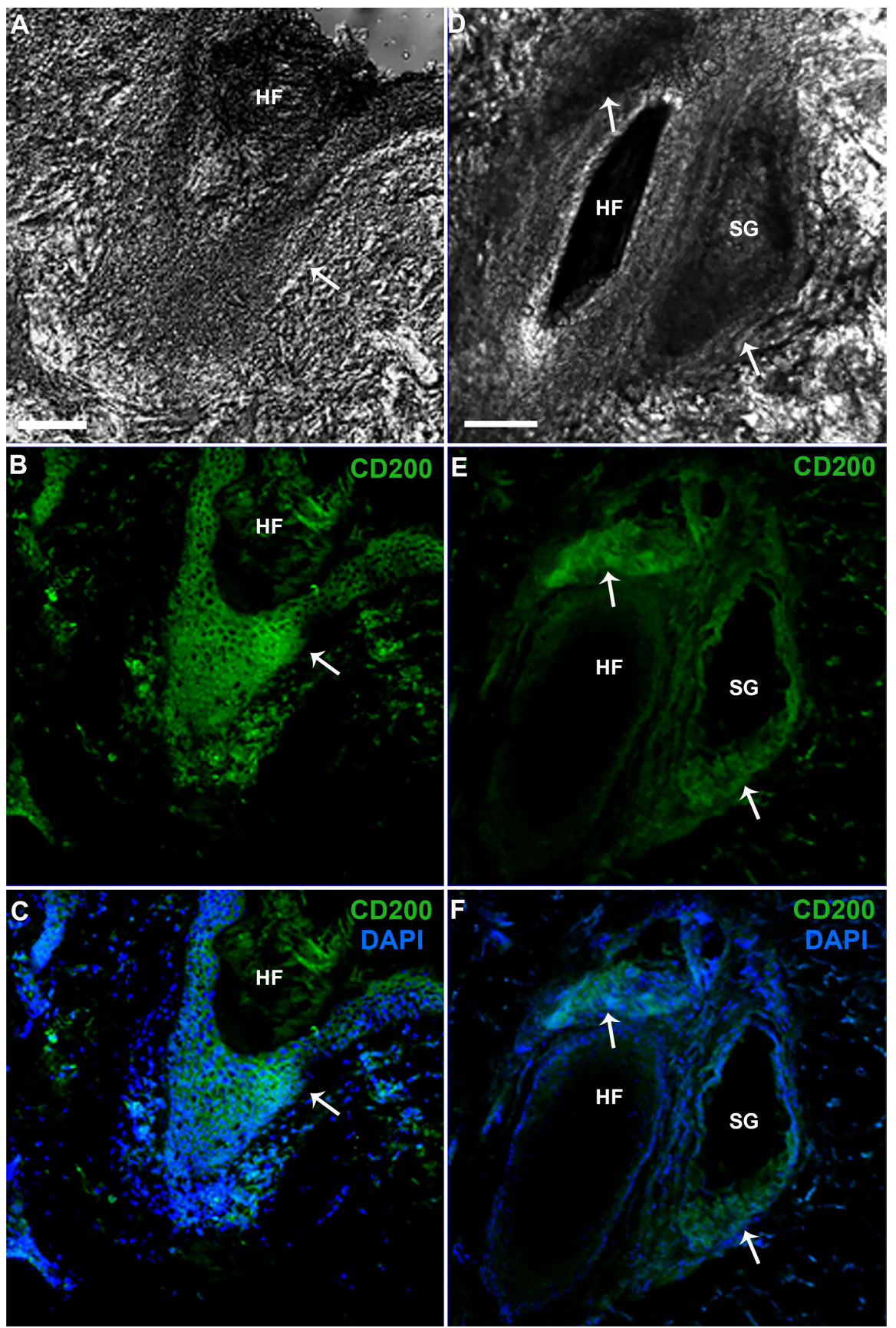

Figure 5. Immunofluorescence of longitudinally sectioned human hair follicles stained for CD200. Confocal microscope. (A)-(F). Panoramic view showing the organization of the HF in the skin. (A) (D). Image DIC. (B), (C), (E) and (F). High CD200 expression in all areas of the bulge region (arrow). Nuclei are counterstained with DAPI. Scale bars = $100 \mu \mathrm{m}$.

This pattern of expression may suggest that follicular cells with a focal immunodetection migrate in the region of prominence from the basement membrane to the bulge region to contribute in tissue regeneration [8] [27] [28], expression being gradually decreased along the follicle. Likewise, the presence of two distinct subsets of multipotent SC, basal and suprabasal layers, has been 
demonstrated in mice and humans, within the protrusion. The first, larger than the second [29] [30] [31], showed cells in diverse stages of differentiation, indicating that they may represent transient amplifying cells or progeny of bulge SC.

In general, the techniques described in this study made it possible to compare and determine the pattern of staining more clearly, using confocal fluorescent microscopy that demarcates individual positive cells of a defined tissue. The results of immunohistochemistry and immunofluorescence evaluation carried out in sections of mouse whiskers and HF of mice and humans and were very useful in differentiating cell expression, revealing that the cells associated with CD34 and CD200 antibodies were differentially expressed in the epidermis, the basal SG, the vibrissae, and HF. This perspective suggests that the CD34 and CD200 biomarkers (in mice and humans, respectively) had greater specificity than CK15 in identifying bulge cells. We also suggest that the sensitivity of the CD34 antibody is higher in cells with SC characteristics in mouse HF, while CD200 might have specificity with characteristics for progenitor cells and partially differentiated cells. The location of intrinsic SC within the HF suggested that they are easily accessible. This important attribute makes these cells valuable candidates for use in vitro studies and in regenerative medicine.

\section{Conclusion}

The Immunohistochemical staining data showed that CD34 in mouse and CD200 in human are reliable markers because they are expressed strongly in the bulge area allowing identification of the niche cells, representing a promising tool for classifying cell populations according to expression levels of stem cell-associated biomarkers.

\section{Acknowledgements}

The authors gratefully acknowledge the support provided and advice on image analysis by Héctor Rojas at the Institute of Immunology at the Central University of Venezuela. We thank Campbell and Dr. Schatten for reviewing the manuscript.

\section{Conflicts of Interest}

The authors declare no conflicts of interest regarding the publication of this paper.

\section{References}

[1] Owens, D.M. and Watt, F.M. (2003) Contribution of Stem Cells and Differentiated Cells to Epidermal Tumours. Nature Reviews Cancer, 3, 444-451. https://doi.org/10.1038/nrc1096

[2] Krause, K. and Foitzik, K. (2006) Biology of the Hair Follicle: The Basics. Seminars in Cutaneous Medicine and Surgery, 25, 2-10. https://doi.org/10.1016/j.sder.2006.01.002

[3] Schneider, M.R., Schmidt-Ullrich, R. and Paus, R. (2009) The Hair Follicle as a Dy- 
namic Miniorgan. Current Biology, 19, R132-R142.

https://doi.org/10.1016/j.cub.2008.12.005

[4] Dry, F.W. (1926) The Coat of the Mouse (Mus musculus). Journal of Genetics, 16, 287-340. https://doi.org/10.1007/BF02983004

[5] Wang, H.-T., Chen, B., Tao, K., Tang, C.-W. and Hu, D.-H. (2007) Human Hair Follicle Bulge Cells: Potential Germ Cells for Skin Tissue Engineering. Journal of US-China Medical Science, 4, 1-8.

[6] Voog, J. and Jones, L.D. (2011) Stem Cells and the Niche: A Dynamic Duo. Cell Stem Cell, 6, 103-115. https://doi.org/10.1016/j.stem.2010.01.011

[7] Pérez, J.C.J., Garza, V.I. and Ortiz, L.R. (2007) Células Madre. Medicina Universitaria, 9, 130-140.

[8] Cotsarelis, G. (2006) Epihelial Stem Cells: A Folliculocentric View. Journal of Investigative Dermatology, 126, 1459-1468. https://doi.org/10.1038/sj.jid.5700376

[9] Amoh, Y., Amoh, Y., Li, L., Katsuoka, K. and Hoffman, R.M. (2009) Multipotent Nestin-Expressing Hair Follicle Stem Cells. Journal of Dermatology, 36, 1-9. https://doi.org/10.1111/j.1346-8138.2008.00578.x

[10] Omary, M.B., Coulombe, P.A. and McLean, W.H.I. (2014) Intermediate Filament Proteins and Their Associated Diseases. The New England Journal of Medicine, 351, 2087-2100. https://doi.org/10.1056/NEJMra040319

[11] Moll, R., Divo, M. and Langbein, L. (2008) The Human Keratins: Biology and Pathology. Histochemistry and Cell Biology, 129, 705-733. https://doi.org/10.1007/s00418-008-0435-6

[12] Lyle, S., Christofidou-Solomidou, M., Liu, Y., Elder, D.E., Albelda, S. and Cotsarelis, G. (1998) The C8/144B Monoclonal Antibody Recognizes Cytokeratin 15 and Defines the Location of Human Hair Follicle Stem Cells. Journal of cell Science, 111, 3179-3188.

[13] Braun, K.M., Niemann, C., Jensen, U.B., Sundberg, J.P., Silva-Vargas, V. and Watt, F.M. (2003) Manipulation of Stem Cell Proliferation and Lineage Commitment: Visualisation of Label-Retaining Cells in Wholemounts of Mouse Epidermis. Development, 130, 5241-5255. https://doi.org/10.1242/dev.00703

[14] Liu, Y., Lyle, S., Yang, Z. and Cotsarelis, G. (2003) Keratin 15 Promoter Targets Putative Epithelial Stem Cells in the Hair Follicle Bulge. The Journal of Investigative Dermatology, 121, 963-968. https://doi.org/10.1046/j.1523-1747.2003.12600.x

[15] Ohyama, M., Terunuma, A., Tock, C.L., Radonovich, M.F., Pise-Masison, C.A., Hopping, S.B., Brady, J.N., Udey, M.C. and Vogel, J.C. (2006) Characterization and Isolation of Stem Cell-Enriched Human Hair Follicle Bulge Cells. The Journal of clinical Investigation, 116, 249-260. https://doi.org/10.1172/JCI26043

[16] Krause, D.S., Ito, T., Fackler, M.J., Smith, O.M., Collector, M.I., Sharkis, S.J. and May, W.S. (1994) Characterization of Murine CD34, a Marker for Hematopoietic Progenitor and Stem Cells. Blood, 84, 691-701.

[17] Simmons, D.L., Satterthwaite, A.B., Tenen, D.G. and Seed, B. (1992) Molecular cloning of a cDNA Encoding CD34, a Sialomucin of Human Hematopoietic Stem cells. Journal of Immunology, 148, 267-271.

[18] Van de Rijn, M. and Rouse, R.V. (1994) CD34: A Review. Applied Immunohistochemistry, 2, 71-80.

[19] Copland, D.A., Calder, C.J., Raveney, B.J., Nicholson, L.B., Phillips, J., Cherwinski, H.M., Jenmalm, M.C., Sedgwick, J.D. and Dick, A.D. (2007) Monoclonal Antibody-Mediated CD200 Receptor Signaling Suppresses Macrophage Activation and 
Tissue Damage in Experimental Autoimmune Uveoretinitis. The American Journal of Pathology, 171, 580-588. https://doi.org/10.2353/ajpath.2007.070272

[20] Tiede, S., Kloepper, J.E., Bódó, E., Tiwari, S., Kruse, C. and Paus, R. (2007) Hair Follicle Stem Cells: Walking the Maze. European Journal of Cell Biology, 86, 355-376. https://doi.org/10.1016/j.ejcb.2007.03.006

[21] Trempus, C.S., Morris, R.J., Bortner, C.D., Cotsarelis, G., Faircloth, R.S., Reece, J.M. and Tennant, R.W. (2003) Enrichment for Living Murine Keratinocytes from the Hair Follicle Bulge with the Cell Surface Marker CD34. The Journal of Investigative Dermatology, 120, 501-511. https://doi.org/10.1046/j.1523-1747.2003.12088.x

[22] Webb, A.N., Li, A. and Kaur, P. (2004) Location and Phenotype of Human Adult Keratinocyte Stem Cells of the Skin. Differentiation, 72, 387-395. https://doi.org/10.1111/j.1432-0436.2004.07208005.x

[23] Blanpain, C. and Fuchs, E. (2009) Epidermal Homeostasis: A Balancing Act of Stem Cells in the Skin. Nature Reviews Molecular Cell Biology, 10, 207-217. https://doi.org/10.1038/nrm2636

[24] Andl, T., Murchison, E.P., Liu, F., Zhang, Y.H., Yunta-Gonzalez, M., Tobias, J.W., Andl, C.D., Seykora, J.T., Hannon, G.J. and Millar, S.E. (2006) The miRNA-Processing Enzyme Dicer Is Essential for the Morphogenesis and Maintenance of Hair Follicles. Current Biology, 16, 1041-1049. https://doi.org/10.1016/j.cub.2006.04.005

[25] Kloepper, J.E., Tiede, S., Brinckmann, J., Reinhardt, D.P., Meyer, W.M., Fässler, R. and Paus, R. (2008) Immunophenotyping of the Human Bulge Region: The Quest to Define Useful in Situ Markers for Human Epithelial Hair Follicle Stem Cells and Their Niche. Experimental Dermatology, 17, 592-609.

https://doi.org/10.1111/j.1600-0625.2008.00720.x

[26] Jiang, S., Zhao, L., Purandare, B. and Hantash, B.M. (2010) Differential Expression of Stem Cell Markers in Human Follicular Bulge and Interfollicular Epidermal Compartments. Histochemistry and Cell Biology, 133, 455-465. https://doi.org/10.1007/s00418-010-0684-Z

[27] Morrison, S.J. and Spradling, A.C. (2008) Stem Cells and Niches: Mechanisms That Promote Stem Cell Maintenance throughout Life. Cell, 132, 598-611. https://doi.org/10.1016/j.cell.2008.01.038

[28] Garcin, C.L., Ansell, D., Headon, D.J., Paus, R. and Hardman, M.J. (2016) Hair Follicle Bulge Stem Cells Appear Dispensable for the Acute Phase of Wound Re-Epithelialization. Stem Cells, 32, 1377-1385. https://doi.org/10.1002/stem.2289

[29] Blanpain, C., Lowry, W.E., Geoghegan, A., Polak, L. and Fuchs, E. (2004) Self-Renewal, Multipotency, and the Existence of Two Cell Populations within an Epithelial Stem Cell Niche. Cell, 118, 635-648. https://doi.org/10.1016/j.cell.2004.08.012

[30] Zhang, Y., Xiang, M., Wang, Y., Yan, J.J., Zeng, Y., Yu, J.H. and Yang, T. (2006) Bulge Cells of Human Hair Follicles: Segregation, Cultivation and Properties. Colloids and Surfaces B Biointerfaces, 47, 50-56. https://doi.org/10.1016/j.colsurfb.2005.11.017

[31] Inoue, K., Aoi, N., Sato, T., Yamauchi, Y., Suga, H., Eto, H., Kato, H., Araki, J. and Yoshimura, K. (2009) Differential Expression of stem-Cell-Associated Markers in Human Hair Follicle Epithelial Cells. Laboratory Investigation, 89, 844-856. https://doi.org/10.1038/labinvest.2009.48 